small provincial schools serve for the education of health visitors. Since 1929, considerable advance has been made in a eampaign against tuberculosis. As regards leprosy, for many years the work was confined to the provision of a number of asylums for lepers, but about fifteen years ago scientific research showed that early cases were amenable to treatment, and in 1934 the British Empire Leprosy Relief Association was founded. In the following year an Indian Council for the Association was inaugurated, and research work was intensified, especially by the Calcutta School of Tropical Medicine.

\section{Disease Among Natives of Alaska}

IN a paper read before the Section on Medical History of the College of Physicians of Philadelphia (Trans. and Stud. Coll. Phys. Philadelphia, 4, Ser. 8, 27 ; 1940) Dr. Joseph D. Aronson, associate professor of bacteriology in the University of Pen sylvania, remarks that though little is known of the occurrence of disease among the natives of Alaska prior to its discovery by the Russian explorer Khirikoff in 1741, the early reports and records indicate that diseases due to food deficiencies existed and that smallpox, syphilis and tuberculosis were unknown and were probably introduced by the white man. Smallpox, which was probably introduced by the Spaniards, caused more suffering and loss of life than any of the other diseases. The mortality was particularly high among adults and considerably less among children. It soon became clear that in parts where vaccination was employed the disease was brought under control and the mortality fell to 10 per cent or less, whereas in areas where the natives refused to be vaccinated the mortality ranged from 40 to 60 per cent. Syphilis was brought into the country by hunters, traders, and especially sailors, and became widespread. There is no record of tuberculosis either in its pulmonary or extrapulmonary form such as lupus or involvement of the bones or joints, until 1770 or twenty-nine years after the discovery of Alaska. Afterwards it spread rapidly, though it did not reach the epidemic proportions of smallpox.

\section{The Illegitimate Child}

Is a review of this subject in the July issue of the Quarterly Review, Mr. Claud Mullins, the well-known Metropolitan police magistrate, remarks that illegitimacy is not only a problem in itself but is also a big contributing factor in prostitution, abortion and crime. He points out that the absence of a father from the beginning of the life of the illegitimate child must have a big effect, as it is the father's function to implant in the child impulses which produce lawabiding citizens. Only too frequently the illegitimate child is a rebel not only against the conventions of society but also against criminal laws. Sometimes the dangers of illegitimacy are minimized by the child's early adoption into a normal and healthy home, but most psychologists agree that even with adoption there may be a trauma in the child's unconscious, and this trauma may result in a later hostility to society. Mr. Mullins suggests that there should be a new bastardy law in which the interests of the child should be uppermost, and that regular maintenance should permit decent arrangements to be made for its upbringing and education. In conclusion he recommends the substitution of the words "natural child" for "bastard", and "child maintenance" or "child paternity proceedings" for "bastardy proceedings".

\section{Treatment of Juvenile Delinquents}

IN his inaugural thesis (Thèse de Paris, No. 1105 ; 1939), Dr. H. Pitoux, who records five illustrative cases, states that of 98 inmates of the Fresnes prison under thirty years of age, 61 had committed their first offence before the age of twenty-one. He recommends that in order to enable a young offender to play a respectable part in society he should undergo a medico-psychological examination, and a careful inquiry be made into his previous social environment. He should then be classified and sent to a centre suitable for his psychical and occupational level. Institutions with a staff specially trained to give the young offender an intellectual, moral and occupational education are needed to enable him to return to society. At the present time only the first part of this programme, namely, the scientific and medico-psychological, has been realized in France, but as regards education much still remains to be done.

\section{Bibliographical and Intelligence Services}

THE Proceedings of the British Society for International Bibliography, 1, Part 1-3 (1939) include a paper by J. E. Wright on the special library and information bureau established in connexion with the Post Office Engineering Research Station at Dollis Hill ; special reference is made to the use of the universal decimal system of classification in the indexing of literature and information relevant to the work of the Department. Dr. S. C. Bradford contributes a note on the co-ordination of documentation, in which the limitations of abstracting periodicals are indicated, and the lack of co-ordination between the abstracting services leading to incompleteness and inconvenience is criticized. Dr. Bradford again argues that abstracting should be organized from the point of view of science as a whole. The information service of the Imperial Bureau of Horticulture and Plantation Crops is described by D. Akenhead. In addition to Horticultural Abstracts, the Bureau has issued twelve technical communications and five occasional papers, one of the latter being an annotated bibliography on the biter pit of apples, and another the translation of conclusions reached by a Russian author on the manuring of fruit trees. Primarily, the information service is for research workers in the Empire, but inquiries from private individuals or from foreign research workers are often handled.

The organization of an industrial intelligence service in relation to documentation is discussed by S. G. Barker, who argues that industry requires a co-ordinating agency for the dissemination of information regarding current work, both published and 
unpublished. It also requires, he considers, historical bibliographies of failures and successes and historical records leading up to and subsequent to them, as well as an intelligent observation of potentialities in regard to the future. These must be expressed to the business man and technologist in brief terse language, so that on straightforward reading he will readily grasp the essentials and be able to indicate to his subordinates and others what he requires in regard to detail. To do this effectively, co-operation, coordination and collaboration with other industrial information sources are essential, and this is the organization we seek.

\section{Books to Read at College}

The Trinity College Bulletin, edited by Prof. H. T. Costello, which comes to us from Hartford, Connecticut, supplies a "List of Books for a College Student's Reading'. This, first published in 1925, has now reached a third, revised edition, and deserves to be popular. The aim of the pamphlet is "to bring the best students and the best books together", helping them to avoid waste of time on inferior stuff. This is an excellent idea in view of the present overcrowded jungle of literature, the reduction of which by the stress of the War will, we hope, be permanent. The general reading course before us is well arranged. The list is divided into ten sections, and students are expected to read and write on something in eight of them. "Reading in the greater classics is likely to get special grade credit." This is as it should be. Early specialization pays to-day and interferes with that versatility which belongs to a liberal education. No censorship of ideas is attempted in the lists, and "books that may shock or annoy" are included. The short descriptions added to each item are expert and helpful.

\section{Meteorites in the Indian Museum}

A CATAlogue of meteorites, with special reference to Indian falls and finds and to specimens in the Indian Museum, Calcutta, has been compiled by A. L. Coulson and published as Memoir 75 of the Geological Survey of India, 1940. An order of the Government of India lays down that all meteorites falling in British India are the property of the Government of India and as such should normally find a place in the Indian Museum under the care of the Geological Survey of India. Every effort is made by the Survey to obtain new falls, and these are carefully studied and the results published in the Records of the Survey.

The first catalogue of the collection was prepared by Thomas Oldham in 1864 and gave particulars of 21 stones and 26 irons. By 1914, when Coggin Brown's catalogue (1916) was compiled, the collection had grown to a total of 379 , though some of the specimens included in this total have since been found to be identical, due to better knowledge of the various synonyms that have been used in the past. Recently there has been active exchange of meteorites with various British and foreign institutions and on August 1, 1939, the collection included 149 irons and 319 stones, a total of 468 falls and finds. The present catalogue deals primarily with Indian falls and finds, but also attempts to include all meteorites, whatever their locality. References to the most important literature dealing with Indian meteorites and a short résumé of the circumstances of fall or find has been given in every case. Other chapters deal with classification, dates of fall or find and geographical distribution.

\section{A New Direction Indicator for an Aeroplane}

According to Science Service, Dr. David Luck has described before the U.S. Institute of Radio Engineers a new form of radio beacon for aeroplanes which has been developed after four years research under his supervision at the laboratory at Central Airport, Camden, N.J. It is called the omnidirectional radio-range beacon, and operates with ultra-highfrequency oscillations to reduce the effect of atmospherics to a minimum. Radio-beacons have been in use for several years, but they serve only to confine the pilot to a definite course. Some air lines have used in addition direction finders to show the direction of the transmitting station from an aeroplane, but these are not satisfactory when using ultra-highfrequencies owing to atmospherics.

Dr. Luck described the operation of the new device as follows. When the pilot has to fly around a portion of his course affected by bad weather, he can always 'see' the direction of the radio-station at a glance. If he wants to fly straight into or out from the beacon, he has only to hold the mark steady, at that course, against a scale on the instrument face. The operation of this indicator may be compared to that of a lighthouse sending out two kinds of light, one a beam which sweeps around steadily and the other a flash sent out in all directions the moment the beam points north. The interval is timed from the flash until the beam sweeps over the observer, and then the required direction from the lighthouse is found. In the new radio device, the radio-lighthouse is on the ground and the indicating instrument on the plane automatically times the flash and beam. All this is done electrically, and the lighthouse beam sweeps round sixty times each second.

\section{Recent Advances in Electroplating}

According to the Electrical Times of August 15, the electroplating of chromium is finding a wide application for purposes other than superficial polish and protection. Recently a German technical paper published an account of the utilization of chromium plating for use with steel cutting tools and bearings. A cheaper grade of steel or even common iron may be employed. The working edge is then plated with chromium, which gives it a hardness comparable to that of diamond. The cutting edge may then be ground, for the chromium may be applied in any thickness, and the tool has all the best features of the hardest and most expensive high-grade steel, its life is multiplied by two or even ten, it wears away far more slowly, and will go through most hard metals as if they were cheese. Bearing journals left 